\title{
PENGARUH PELAYANAN PENDAFTARAN PASIEN RAWAT JALAN TERHADAP KEPUASAN PASIEN DI PUSKESMAS PLAJU PALEMBANG TAHUN 2019
}

\author{
Guna Phantiasa ${ }^{1}$, Leni Wijaya ${ }^{2}$ \\ Program Studi S1 Keperawatan Stikes Mitra Adiguna Palembang. \\ Komplek Kenten Permai Blok J.No Bukit Sangkal Palembang 30114.
}

\begin{abstract}
Abstrak
Puskesmas (health center) adalah suatu kesatuan organisasi fungsional yang langsung memberikan pelayanan kesehatan secara menyeluruh dan terpadu kepada masyarakat dalam satu wilayah kerja tertentu dalam bentuk usaha-usaha kesehatan pokok. Pelayanan yang diberikan oleh puskesmas secara menyeluruh yang meliputi jenjang pelayanan-pelayanan promotif, preventiv, kuratif, dan rehabilitas.Pelayanan pendaftaran pasien rawat jalan merupakan unit pelayanan terdepan bagi setiap puskesmas. Pelayanan pendaftaran pasien harus mampu mencakup informasi penting mengenai data sosial pasien. Pemberi pelayanan sebaiknya berpenampilan rapi dan berkomunikasi aktif untuk mendukung pelayanan di puskesmas.Tujuan penelitian ini adalah untuk mengetahui adanya pengaruh pelayanan pendaftaran pasien rawat jalan terhadap kepuasan pasien Di Puskesmas Plaju Palembang 2019. Penelitian yang digunakan adalah kuantitatif dengan teknik pengambilan sampel secara accidental sampling sebanyak 79 responden.penelitian ini dianalisis menggunakan metode regresi linier sederhanan. Hasil Uji regresi liner sederhana didapat ada pengaruh pada variabel pelayanan pendaftaran dan variabel kepuasan pasien Di Puskesmas Plaju Palembang dengan nilai ( p) sig $(0,000<$ $0,05)$ dan $t$ hitung $6.092>t$ tabel 1.994. Penelitian ini diharapkan dapat menjadi masukan dan pertimbangan untuk mengadakan evaluasi secara rutin bagi pelayanan pendaftaran pasien rawat jalan khususnya di Puskesmas Plaju Palembang dalam meningkatkan pelayanan terutama pelayanan pendaftaran pasien rawat jalan
\end{abstract}

Kata Kunci : Kepuasan Pasien dan Pelayanan Pendaftaran

Abstract

Health Center (health center) is a functional organizational unit that directly provides comprehensive and integrated health services to the community in a particular work area in the form of basic health efforts. Services provided by puskesmas as a whole include levels of promotive, preventive, curative, and rehabilitation services. Outpatient registration services are the leading service units for each puskesmas. Patient registration services must be able to include important information about patient social data. The service provider should look neat and actively communicate to support services at the health center. The purpose of this study was to determine the effect of outpatient registration services on patient satisfaction at the Puskesmas Plaju Palembang 2019. The study used was quantitative with accidental sampling technique as many as 79 respondents. This study was analyzed using the simple linear regression method. Simple Liner regression test results obtained have an influence on the registration service variables and patient satisfaction variables in Plaju Palembang health center with a value ( $p)$ sig $(0,000<0.05)$ and $t$ count 6,092> t table 1,994. This research is expected to be an input and consideration for conducting routine evaluations for outpatient registration services, especially at the Plaju Palembang Health Center in improving services, especially outpatient registration services

Keywords : Patient Satisfaction and Registration Services 


\section{PENDAHULUAN}

Puskesmas (health center) adalah suatu kesatuan organisasi fungsional yang langsung memberikan pelayanan kesehatan secara menyeluruh dan terpadu kepada masyarakat dalam satu wilayah kerja tertentu dalam bentuk usaha-usaha kesehatan pokok. Menyeluruh, dimana pelayanan yang diberikan oleh puskesmas secara menyeluruh yang meliputi jenjang pelayanan-pelayanan promotif, preventiv, kuratif, dan rehabilitas. Sedangkan terpadu yaitu pelayananya mencakup berbagai kegiatan upaya pokok (upaya pelayanan kesehatan dasar).Puskesmas berperan menyelenggarakan upaya kesehatan untuk meningkatkan kesadaran, kemauan dan kemampuan hidup sehat bagi setiap penduduk agar memperoleh derajat kesehatan yang optimal. Dengan demikian puskesmas berfungsi sebagai pusat penggerak pembangunan berwawasan kesehatan, pusat pemberdayaan keluarga dan masyarakat serta pusat pelayanan kesehatan strata pertama (Masruroh, 2015).

Manajemen puskesmas adalah serangkaian kegiatan yang bekerja secara sistematik untuk menghasilkan luaran puskesmas yang efektif dan efisien yang meliputi tiga fungsi yaitu: perencanaan, pelaksanaan, pengendalian, pengawasan dan pertanggungjawaban (Masruroh, 2015). Sedangkan pengertian manajemen diterjemahkan oleh Grant \& Massey dalam Maria (2017), sebagai suatu pendekatan yang dinamis dan proaktif dalam menjalankan suatu kegiatan didalam sebuah organisasi. Di dalamnya mencakup banyak kegiatan, seperti koordinasi dan supervise staf, sumber daya manusia, dan juga sarana.
Proses pengembangan mutu layanan sebuah institusi penyedia layanan kesehatan (health care provider) dapat dipahami melalui berbagai jenis produk dan jasa pelayanan yang ditawarkan kepada masyarakat, segmen pasar atau konsumen produk tersebut, dan harapan (expectation) pengguna jasa pelayanan terhadap kinerja (performance) pelayanan kesehatan yang tersedia. Pelayanan kesehatan yang ditawarkan oleh institusi penyedia layanan keehatan adalah jasa. Bentuk akhir (autcome) dari jasa layanan kesehatan adalah peningkatan status kesehatan individu atau kelompok masyarakat setelah menerima jasa layanan kesehatan (health care/health services (Muninjaya, 2015).

Menurut Rangkuti dalam Kuntoro (2017), Pelayanan yang memuaskan dan berkualitas akan membentuk loyalitas pasien/pelanggan, dan kepuasan sangat erat hubungannya dengan "Word of mouth", maka pelayanan yang memuaskan tersebut juga akan mendatangkan pelanggan baru. Efek selanjutnya akan berlanjut pada proses terbentuknya citra puskesmas yang meningkat. Jasa pelayanan kesehatan akan dirasakan berkualitas oleh para pelanggannya jika hal-hal yang disampaikan kepada para penggunanya melebihi harapan. Penilaian pengguna jasa pelayanan kesehatan akan ditunjukan kepada substansi pesan yang disampaikan, cara penyampaiannya dan kualitas jasa yang diterima para pemakaianya.

Kualitas jasa pelayanan kesehatan akan sangat ditentukan oleh kebutuhan atau ekspektasi pengguna yang sudah terpenuhi dan diterima tepat waktu. kualitas jasa merupakan tingkat keunggulan yang selalu dirancang dengan baik dan dikendalikan 
keunggulannya untuk dapat memenuhi harapan para penggunanya. Ada dua hal yang memperngaruhi kualitas jasa yaitu expected services dan perceived services (Menurut Wyckof dalam Muninjaya, 2015).

Sedangkan tempat penerimaan pasien rawat jalan merupakan unit pelayanan terdepan bagi setiap puskesmas. Pelayanan pendaftaran pasien harus mampu mencakup informasi penting mengenai data sosial pasien. Selain itu pemberi pelayanan sebaiknya berpenampilan rapi dan berkomunikasi aktif untuk mendukung pelayanan di puskesmas. Tata cara melayani pasien dapat dinilai baik bilamana dilaksanakan oleh petugas yang ramah, sopan, tertip dan penuh tanggung jawab (Kuntoro, 2017).

Berdasarkan data kunjungan Puskesmas Plaju pada Tahun 2016 sebanyak 49885 orang, tahun 2017 sebanyak 55959 orang, tahun 2018 sebanyak 40642 orang. dan pengamatan peneliti di Puskesmas Plaju Palembang 2019 masih terdapat permasalahan di bagian pelayanan pendaftaran, hal ini dapat dilihat dengan adanya pasien komplain terhadap petugas tempat pendaftaran pasien (TTP). Komplain pasien komplain yang ditunjukan kepada petugas TTP dikarenakan kurangnya keramahan petugas, kecepatan dalam melayani pendaftaran yang dikarenakan kurang efisiennya dalam melakukan pendataan pasien

Berdasarkan uraian tersebut diatas, maka Peneliti termotivasi untuk melakukan penelitian dengan judul "Pengaruh pelayanan pendaftaran pasien rawat jalan terhadap kepuasaan pasien di Puskesmas Plaju Palembang 2019"

\section{METODE PENELITIAN}

\section{Jenis Penelitian}

Jenis penelitian yang akan digunakan adalah penelitian kuantitatif. Penelitian kuantitatif merupakan jenis penelitian yang analisisnya secara umum memakai analisis statistik. Karenanya, dalam penelitian kuantitatif pengukuran terhadap gejala yang diamati menjadi penting

\section{Waktu dan Tempat Penelitian}

Penelitian ini direncanakan mulai 28 Maret sampai 28 April tahun 2019 di Puskesmas Plaju Palembang 2019.

\section{Target/Subjek Penelitian}

Pengambilan sampel pada penelitian ini dilakukan dengan cara non random sampling menggunakan metode accidental yaitu pengambilan sampel yang tidak berdasarkan perencanaan, melainkan karena spontanitas (Jenita, 2016). pengumpulan data dilakukan dengan menggunakan daftar pertanyaan berstruktur (Kuesioner) yang diisi oleh pasien pelayanan pendaftaran di Puskesmas Plaju Palembang. dilakukan didasarkan pada suatu pertimbangan tertentu yang dibuat oleh penelitian sendiri, berdasarkan ciri atau sifat sifat populasi yang sudah diketahui sebelumnya

\section{Kriteria Inklusi}

Pasien kunjungan di pelayanan pendaftaran rawat jalan Puskesmas Plaju,Dapat membaca dan menulis, Usia 18- 65 tahun , Bersedia menjadi Responden dan mengisi kuesioner

Kriteria Eksklusi:

Bukan pasien kunjungan pendaftaran rawat jalan Puskesmas Plaju, Tidak bersedia menjadi Responden. 


\section{Prosedur}

Jenis penelitian ini kuantitatif dengan teknik accidental sampling yang dianalisis menggunakan metode regresi linier sederhana.

Pengumpulan data melalui dokumen seperti arsip data dari Puskesmas Plaju Palembang. Peneliti menjelaskan kepada koresponden yang memenuhi kriteria inklusi tentang penelitian yang akan dilakukan, menanyakan kepada koresponden apakah bersedia menjadi responden dalam penelitian atau tidak. Serta membagikan lembar persetujuan untuk menjadi responden dalam penelitian (Informed Consent), Peneliti membagikan kuisioner kepada responden dan responden melakukan pengisian kuisioner. kemudian hasil dari kuesioner di lakukan pengolahan data.

Data, Instrumen, dan
$\begin{gathered}\text { Pengumpulan Data } \\ \text { Penelitian }\end{gathered}$ ini menggunakan instrument penelitian lembar kuesioner pelayanan pendaftaran dan kepuasan pasien di Puskesmas Plaju.

Data dimasukan dalam master tabel dan pengolahan data dilakukan melalui analisis statistik dengan menggunakan komputer.

\section{Teknik Analisa Data}

Analisa data yang digunakan untuk melihat distribusi frekuensi dari tiap-tiap variabel yaitu kualitas pelayanan pendaftaran dan tingkat kepuasan pasien di pelayanan pendaftaran Puskesmas plaju Palembang 2019.

Analisis bivariat merupakan analisa yang dilakukan terhadap dua variabel yang diduga mempunyai pengaruh. Sebelum dilakukan analisis, data yang didapatkan diuji normalitas terlebih dahulu untuk mengetahui distribusi data yang didapatkan.
Uji Normalitas yang digunakan dalam penelitian ini adalah menggunakan uji $\mathrm{T}$ hitung.

kriteria penerimaan dan penolakan hipotesis jika:

1. $t_{\text {hitung }}>t_{\text {tabel }}$ atau signifikan $\leq 0,05$, maka hipotesis nol (HO) ditolak dan hipotesis alternatif (Ha) diterima.

2. $t_{\text {hitung }} \leq \mathrm{t}_{\text {tabel }}$ atau signifikan $>0,05$, maka hipotesis nol (HO) diterima dan hipotesis alternative (Ha) ditolak.

\section{HASIL DAN PEMBAHASAN}

Hasil analisi didapatkan Setelah dilakukannya uji regresi linier sederhana didapatkan nilai signifikan $p=0,000<0,05$. hal tersebut dapat dibuktikan hasil regresi yang telah di uji menunjukan bahwa nilai $t_{\text {hitung }}>t_{\text {tabel }}=5.065>1,991$, hal ini menunjukan bahwa Ho ditolak Ha diterima yang artinya pelayanan pendaftaran berpengaruh signifikan terhadap kepuasan pasien. Adapun persaman garis regresi menggunakan metode kuadrat terkecil (least aquares method) yang didapat $\mathrm{y}=0,901+$ 0,483 .

\section{Analisis Univariat}

Jumlah responden pada penelitian ini adalah 79 yang dikelompokan menjadi 3 kategori yaitu Baik ( jika total skor 82-100), cukup baik ( jika total skor 52-81), tidak baik (jika total skor 22-51).

Tabel 1. Distribusi Frekuensi Responden Berdasarkan Pelayanan Pendaftaran Di Puskesmas Plaju Palembang.

\begin{tabular}{cccc}
\hline NO & $\begin{array}{c}\text { Pelayanan } \\
\text { Pendaftaran }\end{array}$ & Frekuensi & Persentase \\
\hline 1. & Baik & 26 & $32,9 \%$ \\
2. & Cukup baik & 53 & $67,1 \%$ \\
3. & Tidak baik & - & - \\
& Total & 79 & $100 \%$ \\
\hline
\end{tabular}


Hasil analisis berdasarkan tabel 1 di atas univariat dari variabel pelayanan pendaftaran dari 79 responden yang diteliti responden yang pelayanannya baik sebanyak 26 responden $(32,9 \%)$, sedangkan cukup baik 53 responden $(67,1 \%)$, dan responden yang pelayanan pendaftarannya tidak baik tidak ada (0).

Jumlah responden pada penelitian ini adalah 79 yang dikelompokan menjadi 3 kategori yaitu Puas ( jika total skor 74-100), cukup puas ( jika total skor 47-74), tidak puas (jika total skor 20-46).

Tabel 2. Distribusi Frekuensi Responden Berdasarkan kepuasan pasien Di Puskesmas Plaju Palembang 2019.

\begin{tabular}{cccc}
\hline NO & $\begin{array}{c}\text { Kepuasan } \\
\text { Pasien }\end{array}$ & $\begin{array}{c}\text { Frekuen } \\
\text { si }\end{array}$ & Persentase \\
\hline 1. & Puas & 23 & $29,1 \%$ \\
2. Cukup Puas & 56 & $70,9 \%$ \\
3. & Tidak Puas & - & - \\
& Total & 79 & $100 \%$ \\
\hline
\end{tabular}

berdasarkan tabel 2. diatas Hasil analisis univariat dari variabel pelayanan pendaftaran. bahwa distribusi frekuensi responden berdasarkan kepuasan pasien menunjukan bahwa dari 79 responden yang diteliti responden yang kepuasan pasiennya puas sebanyak 23 responden $(29,1 \%)$, sedang yang cukup puas sebanyak 56 responden $(70,9 \%)$, dan responden yang tidak puas tidak ada (0).

\section{Analisis Bivariat}

Analisa ini dilakukan untuk mengetahui adanya Pengaruh pelayanan pendaftaran pasien rawat jalan terhadap kepuasaan pasien di Puskesmas Plaju
Palembang dengan taraf signifikan $\alpha=0,05$ dimana ketentuannya adalah jika nilai $p$ value $>\alpha$ (005) berarti tidak ada pengaruh dan jika $p$ value $<\alpha$ (005) berarti ada pengaruh. Jumlah responden dalam penelitian ini adalah 79 responden.

Tabel.3. Pengaruh pelayanan pendaftaran pasien rawat jalan terhadap kepuasaan pasien di Puskesmas Plaju Palembang 2019".

\begin{tabular}{cccccc}
\hline Model & \multicolumn{2}{l}{$\begin{array}{l}\text { Unstanddized } \\
\text { Coefficients }\end{array}$} & $\begin{array}{c}\text { Standartized } \\
\text { Coefficient }\end{array}$ & $\mathrm{t}$ & Sig \\
\hline & $\mathrm{B}$ & Std & Beta & & \\
& & Error & & & \\
& .901 & .166 & & 5.442 & .000 \\
(Constant) & .483 & .095 & 500 & 5.065 & .000 \\
\hline
\end{tabular}

Berdasarkan Hasil penelitian diatas menunjukan bahwa didapatkan nilai constant (a) sebesar 0,901 sedangkan nilai pelayanan pendaftaran (b/koefisien regresi) didapatkan sebesar 0,483.

Nilai $t_{\text {hitung }}=5.065$ nilai ini digunakan dalam pengujian terhadap koefisien regresi untuk mengetahui variabel independen ( pelayanan pendaftaran) berpengaruh signifikan terhadap perubahan nilai variabel dependen (kepuasan pasien). berdasarkan nilai $t_{\text {tabel }}$ dengan derajat kebebasan untuk taraf kesalahan 5\% dengan $\mathrm{n}=79$ dan $\mathrm{k}$ (jumlah variabel dependen) $=1$ diperoleh $(\mathrm{df}) \mathrm{n}-\mathrm{k}-1$ $=79-1-1=1,991$ maka dapat diambil kesimpulan $t_{\text {hitung }}>\mathrm{t}_{\text {tabel }}=5.065>1,991$, hal ini menunjukan bahwa Ho ditolak $\mathrm{Ha}$ diterima yang artinya pelayanan pendaftaran berpengaruh signifikan terhadap kepuasan pasien. Adapun persaman garis regresi menggunakan metode kuadrat terkecil (least aquares method) yang didapat $\mathrm{y}=0,901+$ 0,483 .

Pelayanan pendaftaran pasien rawat jalan merupakan unit pelayanan terdepan 
bagi setiap puskesmas. Pelayanan pendaftaran pasien harus mampu mencakup informasi penting mengenai data sosial pasien. Selain itu pemberi pelayanan sebaiknya berpenampilan rapi dan berkomunikasi aktif untuk mendukung pelayanan di puskesmas. Tata cara melayani pasien dapat dinilai baik bilamana dilaksanakan oleh petugas yang ramah, sopan, tertip dan penuh tanggung jawab (Kuntoro, 2017).

Berdasarkan hasil penelitian Nur Maulida,(2016) yang berjudul pengaruh pelayanan terhadap kepuasan pasien rawat jalan pada Puskesmas pembantu desa menamang kanan kecamatan muara Kaman Kabupaten Kutai Kartanegara jenis penelitian ini kuantitatif dengan cara membagikan kuesioner. sampel pada penelitian ini sebanya 89 responden dengan cara pemilihan sampel random sampling dengan analisis regresi linern berganda dan pengujian menggunakan uji $\mathrm{F}$ dan uji t. hasil penelitian inimenunjukan ada hubungan yang signifikan atau searah antara variabel reliability, responsiveness, assurance, emphaty, tangible terhadap kepuasan konsumen pada puskesmas pembantu desa menamang kanan.

\section{KESIMPULAN}

Berdasarkan hasil penelitian dari tanggal 28 Maret - 28 April 2019 di Puskesmas Plaju Palembang 2019 dengan 79 responden dapat disimpulkan sebagai berikut:

1. Distribusi frekuensi responden berdasarkan usia sebagian besar responden berusia > 61 tahu $(91,04 \%)$ dan distribusi frekuensi berdasrkan jenis kelamin mayoritas perempuan 61 $(91,04 \%)$.
2. Distribusi frekuensi berdasarkan pelayanan pendaftaran menunjukan bahwa pelayanan yang cukup baik 53 responden $(67,1 \%)$ dan responden yang kualitas pelayanan yang tidak baik tidak ada $(0)$.

3. Distribusi frekuensi responden berdasarkan kepuasan pasien menujukan bahwa yang kepuasanya pasien puas sebanyak 23 responden (29,1\%), responden yang cukup puas 56 responden $(70,9 \%)$, dan yang kualitas pelayananya tidak puas tidak ada (0).

4. berdasarkan nilai tabel dengan derajat kebebasan untuk taraf kesalahan 5\% dengan $\mathrm{n}=79$ dan $\mathrm{k}$ (jumlah variabel dependen $)=1$ diperoleh $(\mathrm{df}) \mathrm{n}-\mathrm{k}-1=79$ $1-1=1,991$ maka dapat diambil kesimpulan $t_{\text {hitung }}>t_{\text {tabel }}=5.065>1,991$, hal ini menunjukan bahwa Ho ditolak $\mathrm{Ha}$ diterima yang artinya pelayanan pendaftaran berpengaruh signifikan terhadap kepuasan pasien. Adapun persaman garis regresi menggunakan metode kuadrat terkecil (least aquares method) yang didapat $\mathrm{y}=0,901+0,483$.

\section{SARAN}

\section{Bagi Puskesmas PlajuPalembang}

Penelitian ini diharapkan dapat menjadi masukan dan pertimbangan untuk mengadakan evaluasi secara rutin bagi pelayanan pendaftaran pasien rawat jalan khususnya di Puskesmas Plaju Palembang dalam meningkatkan pelayanan terutama pelayanan pendaftaran pasien rawat jalan

\section{Bagi Peneliti Selanjutnya}

Sebagai bahan masukan bagi peneliti yang akan datang untuk melakukan penelitian lebih mendalam tentang pengaruh pelayanan pendaftaran terhadap kepuasan 
pasien rawat jalan terutama mengenai teoriteori terbaru mengenai kepuasan pasien dengan menggunakan metode analisis yang berbeda.

\section{DAFTAR PUSTAKA}

Doli, Jenita. 2016. Metodologi penelitian Keperawatan.Yogyakarta:

Pustakabarupress.

Jenitha, Kiky. 2018. Pengaruh Kualitas terhadap kepuasan pasien RSU Surya Husada Di Denpasar Tahun 2018. Jurnal Management Unud, Vol 7, No. 5, $\underline{2018 .}$

Kuntoro, Wahyu. 2017. Kepuasan Pasien Terhadap Kualitas Pelayanan Di Tempat Pendaftaran Pasien Rawat Jalan Puskesmas Kretek Bantul Yogyakarta Tahun 2017. Jurnal Kesehatan Vokasional, Vol.2 No. 1, Mei 2017.

Laela, Ma'rifatun. 2009. Pengaruh Pelayanan Pendaftaran Pasien Rawat Jalan Terhadap Kepuasan Pasien Di Rumah Sakit Umum Daerah Wates Tahun 2009.

Maulida, Nur. 2015. Pengaruh pelayanan terhadap kepuasan rawat jalan pada puskesmas pembantu Desa Menamang kanan kecamatan muara Kaman Kabupaten Kutai Kartanegara tahun 2015.

Masruroh. 2015. Organisasi dan Manajemen Pelayanan Kesehatan Kebidanan. Yogyakarta: Nuha Medika.
Muninjaya. 2015. Manajemen Mutu Pelayanan Kesehatan. Jakarta: Buku Kedokteran EGC.

Maulida, Nur. 2015. Pengaruh Pelayanan Terhadap Kepuasan Pasien Rawat Jalan Pada Puskesmas Pembantu Desa Menamang Kanan Kecamatan Muara Kaman Kabupaten Kutai Kartanegara Tahun 2015.

Nofianan, Hendri. 2011. Hubungan mutu pelayanan pendaftaran dengan kepuasan pasien rawat jalan di Rumah Sakit PKU Muhammadiyah Karanganyar Tahun 2018. Jurnal kesehatan, ISSN. 1997-9551, VOL. V NO.1, Maret2011.

Nursalam. 2011. Manajemen Keperawatan Aplikasi dalam Praktik Keperawatan Profesional. Jakarta: Salemba Medika.

Notoatmodjo, Soekidjo. 2012. Metode penelitian kesehatan. Jakarta : Rineka Cipta.

Nasution. 2010. Manajemen Jasa Terpadu. Bogor: Ghalia Indonesia.

Ratminto. 2018. Manajemen Pelayanan pengembangan model konseptual, penerapan citizen's Charter dan Standar Pelayanan Minimal. Yogyakarta: Pustaka Pelajar.

Swastha Dharmmesta, Basu. 2016. Manajemen Pemasaran Analisis Perilaku Konsumen. Yogyakarta: 2016

Utami, Aulia.2016. Hubungan Waktu Tunggu Pendaftaran dengan 
kepuasan pasien di tempat pendaftaran pasien rawat jalan (TPPRJ) di RSUD Sukoharjo.

Wawan dkk. 2010. Teori \& Pengukuran Pengetahuan, Sikap dan Prilaku Manusia. Yogyakarta: Nuha Medika.

Yeni, Indira. 2017. Kepuasan Pasien TNI Terhadap Pelayanan Pendaftaran rawat jalan dengan metode Importance Performance Analysisi di RSPAU Dr. Hardjolukito.j. Jurnal Kesehatan Vokasional,Vol 1, No 2, April 2017. 